\title{
A NEW BRACHYTHECIUM (BRACHYTHECIACEAE, BRYOPHYTA) FROM THE RUSSIAN FAR EAST
}

\author{
НОВЫЙ ВИД ВRАСНYТНЕСIUM (BRACHYTHЕCIACEAE, BRYOPHYTA) \\ С РОССИЙСКОГО ДАЛЬНЕГО ВОСТОКА
}

\author{
Michael S. IGNATOV ${ }^{1,2}$, AlinA V. FedOROVA ${ }^{2} \&$ AleXEY V. TROITSKY $^{3}$ \\ МИХАИЛ С. ИГНАТОВ ${ }^{1,2}$, АЛИНА В. ФЕДОРОВА ${ }^{2}$, АЛЕКСЕЙ В. ТРОИЦКИЙ ${ }^{3}$
}

Abstract

\begin{abstract}
Molecular phylogenetic studies revealed among collections from the Russian Far East an undescribed species of the genus Brachythecium. Morphological distinctions of $B$. amurense sp. nov. disagree with any species closely related according to the analysis of the nuclear ITS, the marker explored in most studied species of the genus. The fact that such large and conspicuous plant remained undiscovered indicates still incomplete knowledge of mountain moss flora of the Russian Far East and calls for more efforts for its exploration.
\end{abstract}

Резюме

В результате молекулярно-филогенетического анализа в коллекциях с российского Дальнего Востока выявлен не описанный вид из рода Brachythecium. Морфологические признаки $B$. amurense sp. nov. отличаются от признаков всех видов, которые близки к нему согласно резульатам анализа последовательностей ядерного маркера ITS, изученного у большинства видов рода, для которых была исследована ДНК. Тот факт, что такое крупное, хорошо отличающееся растение до сих пор оставалось не описанным, свидетельствует о недостаточной изученности бриофлоры гор Дальнего Востока и о необходимости прилагать больше усилий для ее изучения.

KEYWORDS: mosses, taxonomy, molecular phylogenetic, new species, Russia

\section{INTRODUCTION}

The genus Brachythecium, even after splitting off Sciuro-hypnum and Brachytheciastrum (Ignatov \& Huttunen, 2002) remains one of the largest genera in the moss flora of temperate regions of Northern Hemisphere (Hill et al., 2006; Iwatsuki, 2004; Noguchi \& Iwatsuki, 1991; Takaki, 1955, 1956; Wang, 2008; Ignatov, 2014) in general and moss flora of Russia in particular. In addition to this, recent molecular phyligenetic studies considerably increased the number of species of the genus in Russia. The last check-list of mosses of Russia (Ignatov et al., 2006) included 20 species of Brachythecium. Subsequently, the broad screening with molecular markers tracked out the most obvious underdescribed lineages (Ignatov et al., 2008; Ignatov \& Milyutina, 2010), thus a preliminary treatment of the genus Brachythecium for the Moss Flora of Russia (version 14.IV.2012, http://http://arctoa.ru/ Flora/taxonomy-ru/Brachythecium-text-russian.pdf) included already 29 species. Subsequent sequencing of enigmatic specimens mostly revealed range extension of some recent- ly described species (Kuznetsova et al., 2019), but one sample appeared to be conspicuous in morphology, as well as in sequence data, so it is described here as a new species.

The specimen was collected in alpine belt of TardokiYani Mt., a bryological hotspot area. The catalogue of its moss flora was published by Fedosov et al. (2016) and this specimen was referred to $B$. garovaglioides, as this species superficially is most similar with this plant. However, more detailed investigation with the help of molecular markers showed that this indentification needs reconsideration.

\section{MATERIAL AND METHODS}

Taxon sampling included 51 accessions with outgroup genus, Brachytheciastrum, closely related to Brachythecium. The genus Brachythecium was represented by 50 accessions from 23 species, evenly covering the diversity of the genus in Russia. This sampling came out from the reduction of larger dataset, over 150 accessions, taken from GenBank by maximin similarity to specimen in question using BLAST search and alignments from our

1 - Lomonosov Moscow State University, Faculty of Biology, Plant Ecology and Geography Dept., Leninskie Gory Str. 1-12, Moscow 119234 Russia - Россия, 119234, Москва, Ленинские Горы, д. 1 стр. 12, Московский государственный университет, биологический факультет, кафедра экологии и географии растений; e-mail: misha_ignatov@list.ru

2 - Tsitsin Main Botanical Garden, Russian Academy of Sciences, Botanicheskaya Str., 4, Moscow 127276 Russia - Pоссия 127276 Москва, Ботаническая 4, ГБС РАН; e-mail: alina 77777@mail.ru;

3 - A.N.Belozersky' Research Institute of Physico-Chemical Biology, Moscow State University, Moscow 119991 Russia - Pоссия 119991 Москва, МГУ, НИИ Физико-химической биологии им. А.Н. Белозерского; bobr@belozersky.msu.ru 
Рис. 1. Bayesian tree based on nuclear ITS sequences, showing the position of Brachythecium amurense (new ITS seuqence MN850395, from the holotype).

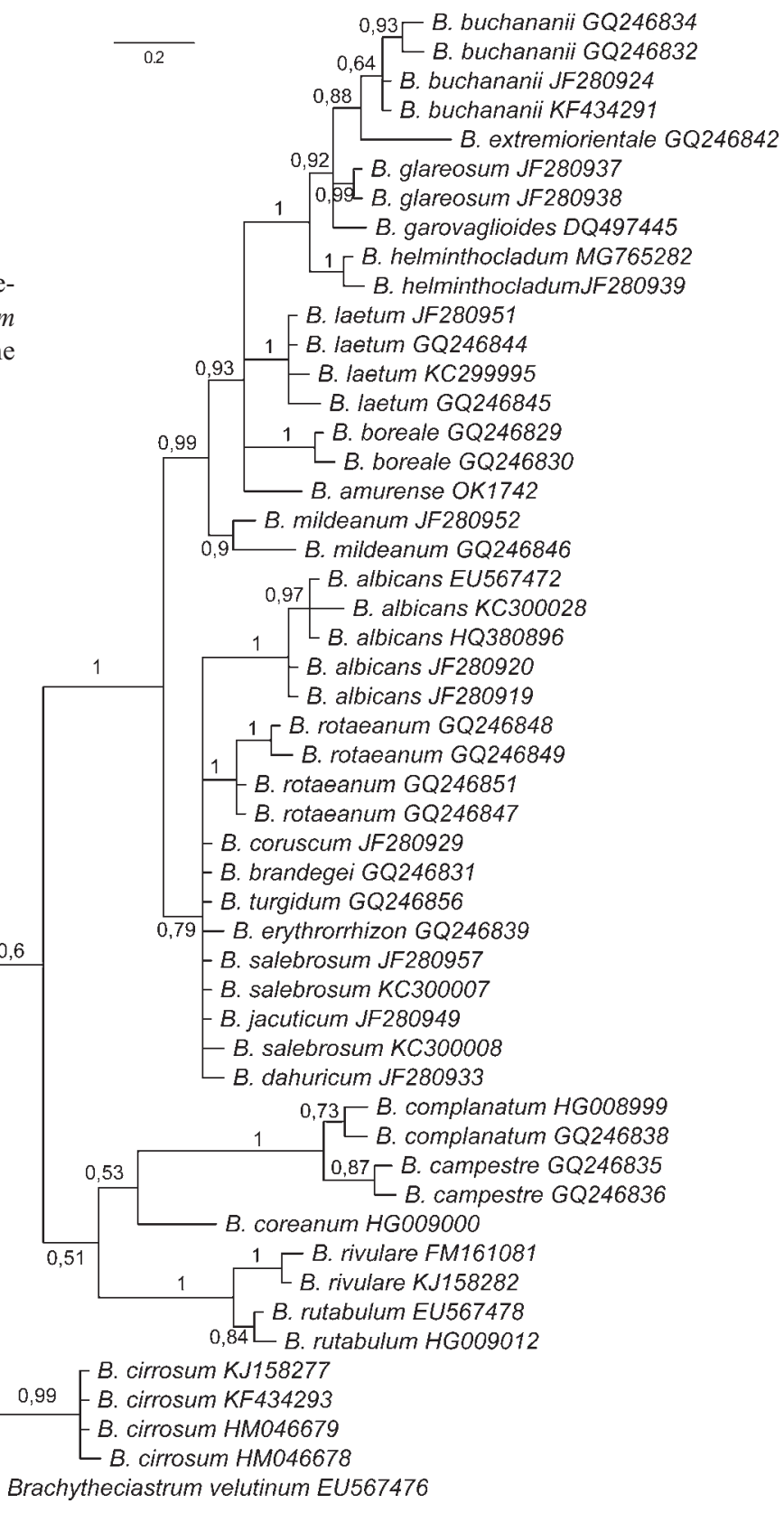

previous studies. Preliminary trees inferred from this larger dataset had topology already found in the genus in earlier studies (Huttunen \& Ignatov, 2004; Ignatov \& Milyutina, 2010), thus numerous repeats of overrepresented species were removed.

Nuclear ITS region was selected, as the most variable and at moment the only suitable at the species level in the genus, where some morphologically distinct species have no one or only one substitution in ITS (cf. Ignatov \& Milyutina, 2010). Laboratory protocols and information about PCR primers are given in Huttunen and Ignatov (2010) and Huttunen et al. (2008). DNA sequences were aligned by Clustal in Bioedit (Hall, 1999), with subsequent manual editing, in fact very small one. Phylogenetic analysis was conducted in MrBayes (Huelsenbeck \& Ronquist,
2001) using the GTR $+\mathrm{G}$ model. It was run for 10000 000 generations with sampling every 1000 generations. The first $25 \%$ of sampled trees were discarded for the burn-in.

\section{RESULTS}

The molecualar phylogenetic analysis resolved Brachythecium with the basal grade of species with rough seta, and two terminal clades of species with smooth setae: (1) B. salebrosum-B. albicans-clade $(\mathrm{PP}=0.79)$, and (2) B. mildeanum-B. laetum-B. buchananii-clade $(\mathrm{PP}=0.99)$. In the latter, $B$. mildeanum-clade $(\mathrm{PP}=0.9)$ is sister to other species, which clade $(\mathrm{PP}=0.93)$ forms a tetratomy of (1) B. buchananii-clade $(\mathrm{PP}=1)$; (2) B. laetum-clade ( $\mathrm{PP}=1)$; (3) B. boreales-clade $(\mathrm{PP}=1)$ and (4) Brachythecium from Tardoki-Yani Mt. 

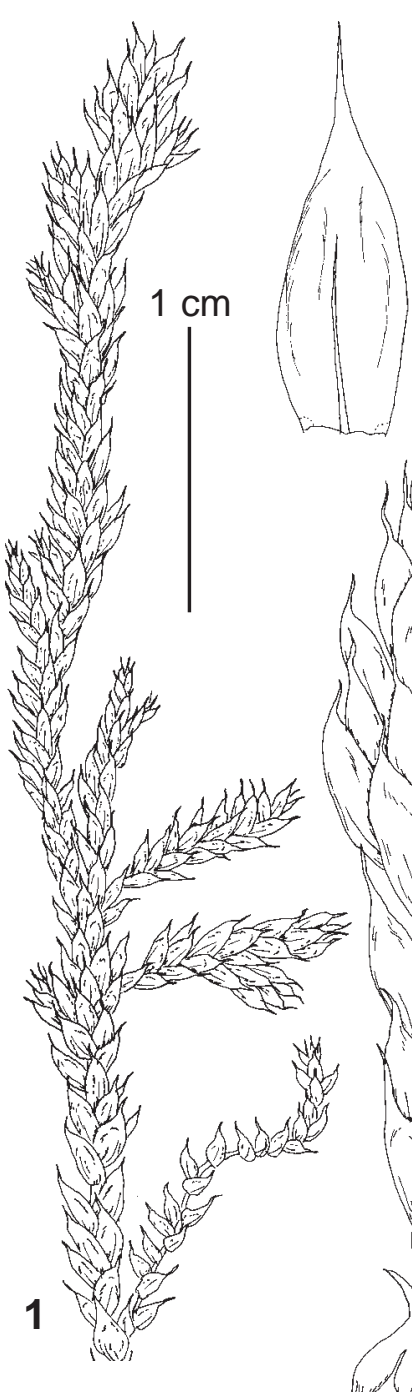

3

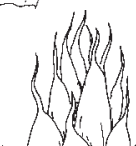

$10 \sqrt{3}$

Q.
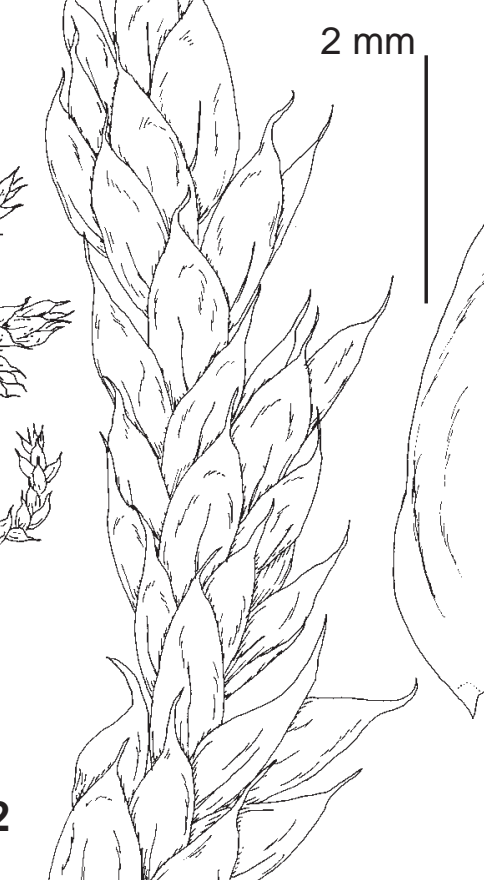

(i...
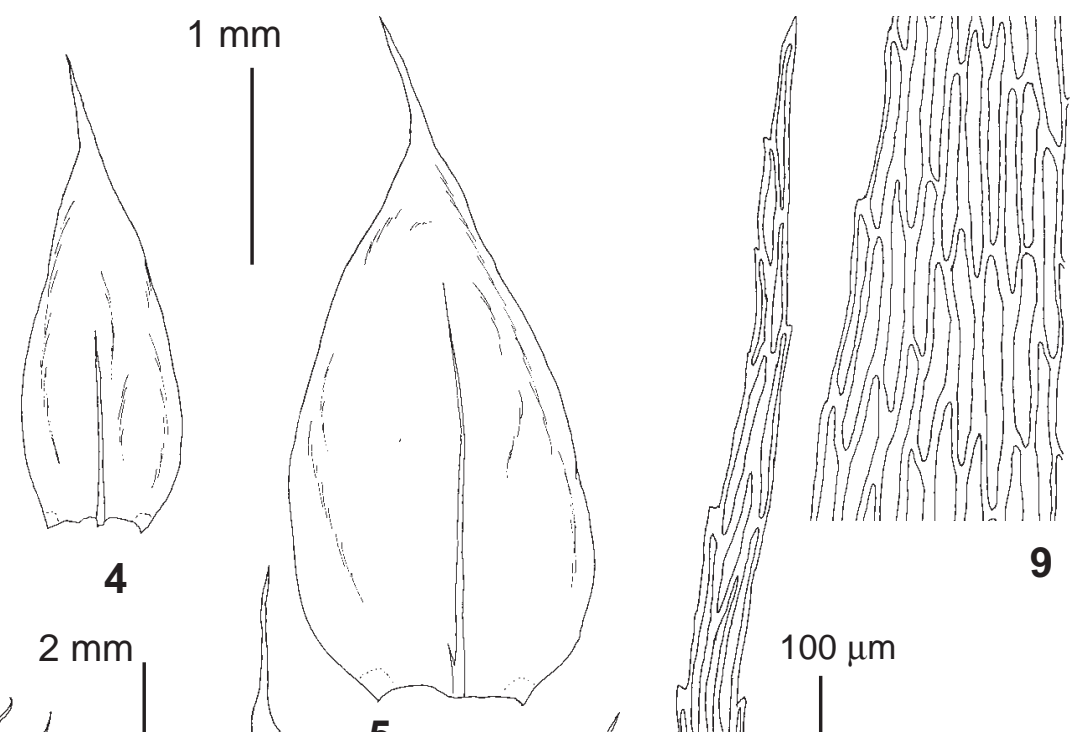

9

\section{$100 \mu \mathrm{m}$}

8

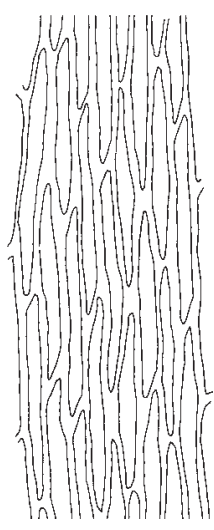

10

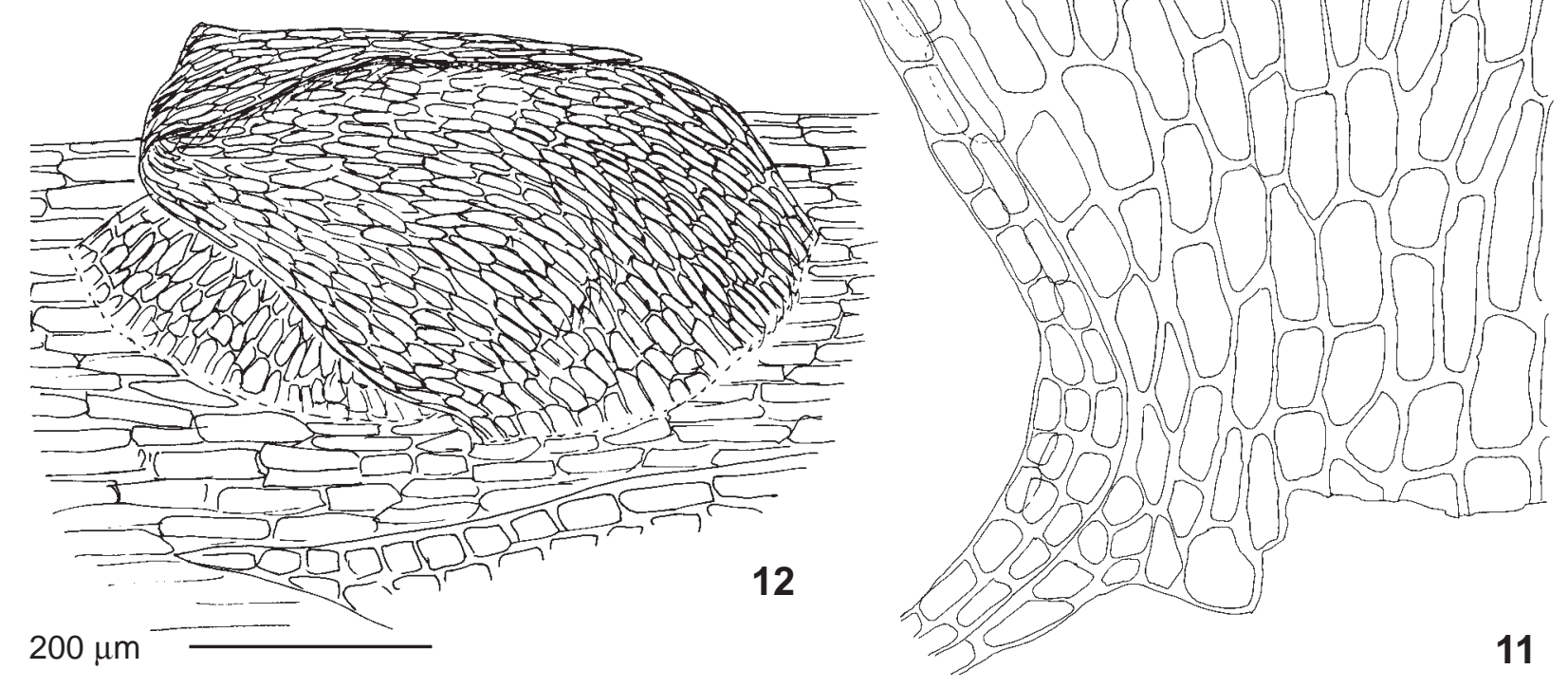

Fig. 2. Brachythecium amurense (from holotype). 1, 2- habit, dry; 3-4-branch leaves; 5-7-stem leaves; 8 - upper laminal cells; 9-10 - median laminal cells; 11- basal laminal cells; 12 - branch primordium (stem apex on the righth). Scale bars: $1 \mathrm{~cm}$ for 1; $2 \mathrm{~mm}$ for $2 ; 1 \mathrm{~mm}$ for $3-7 ; 200 \mu \mathrm{m}$ for $12 ; 100 \mu \mathrm{m}$ for $8-11$. 


\section{TAXONOMY}

Indefinite phylogenetic position of the specimen in question (Fig. 1), with all nearest groups strongly different in morphology left no other choise than a description of a new species.

\section{Brachythecium amurense Ignatov, sp. nov.}

Type: Russia, Khabarovsk Territory, North SikhoteAlin, ca. $1 \mathrm{~km}$ westward of Tardoki-Yani Mt. Peak, N: 48 53'16.9”, E: $138^{\circ} 02^{\prime} 52.8^{\prime}$ ', $1940 \mathrm{~m}$, on soil. Coll. A.V. Ermolenko \#7-4, 24.VIII.2013 (Holotype MW9112512, Isotype MHA).

Diagnosis. Differs from other species in combination of (1) robust pale-stramineous plants, weakly branched stems, terete foliate shoots; (2) leaves with ovate base, subpiliferous distally, strongly concave, crumply plicate; (3) margins minutely serrulate almost all around; (4) laminal cells $65-70(-90) \times 7-10 \mu \mathrm{m}$, moderately thick-walled, porose; (5) alar cells wider, extending upwards.

Description. Plants large, light yellowish-green, glossy, soft, forming loose tufts; outermost proximal branch leaf in branch primordia in 12 o'clock position, abruptly acuminate and consistently squarrose; axillary hairs with one apical and two basal cells, 45-60 $\mu \mathrm{m}$ long. Stems to $8 \mathrm{~cm}$ long, simple, with few short branches or irregularly branched, terete-foliate. Leaves erect-spreading to spreading when dry, crumpled, erect-spreading to loosely appressed when moist, $2-3 \times 1.0-1.3 \mathrm{~mm}$, ovate to ovate-triangular, widest at $1 / 6$ the leaf length, abruptly narrowed into long filiform acumen, strongly concave (forming deep plicae in slides); margins plane or narrowly recurved at base and at the constriction to acumen, weakly serrulate in upper 3/4, subentire below; costa single, weak, quickly narrowing upwards, extending to $1 / 2-$ $3 / 4$ the leaf length; median laminal cells linear, 65-70(-90) $\times 7-10 \mu \mathrm{m}$, slightly porose; basal laminal cells elongaterectangular, 60-75×15-20 $\mu \mathrm{m}$, porose; alar group moderately delimited; alar cells in several submarginal rows, not extending to costa, short-rectangular, 35-50×25-30 $\mu \mathrm{m}$, moderately thick-walled, slightly porose. Apparently dioicous. Gametangia and sporophytes unknown.

Differentiation. Robust habit, crumply plicate leaves, and pattern of basal cell differentiation of $B$. amurense are similar to $B$. garovaglioides and, partly, also to $B$. complanatum. However, both these species have coarsely serrate leaves, and they belong to phylogenetically distant groups (Fig.1). According to the obtained phylogeny, the closest to $B$. amurense are B. mildeanum (differs in entire leaf margins of rather narrowly triangular shape), $B$. laetum (differs in strongly plicate leaves and expanded group of opaque basal cells), and $B$. boreale (differs in medium-sized plants, rather short acumina, dense areolation throughout the leaf, except for a small group of enlarged cells in leaf corners).

Ecology. The species was collected at $1940 \mathrm{~m}$ a.s.1., in alpine belt, on soil on moist open slope, with Philono- tis fontana, Loeskypnum badium, Campylium stellatum, and Hylocomiastrum pyrenaicum.

The finding of such large and conspicuous moss once again illustrates the poor knowledge of of high mountain diversity in Far Eastern region.

\section{ACKNOWLEDGEMENTS}

We thank support of the molecular study from RFBR 18-04-00574. The work was carried out in accordance with MBG Institutional research project 18-118021490111-5.

\section{LITERATURE CITED}

FEDOSOV, V.E., A.V. ERMOLENKO, D.E. KOLTYSHEVA \& V.A. BAKALIN. 2016. On the moss flora of Tardoki-Yani Mountain (North Sikhote-Alin, Russian Far East). - Arctoa 25(2): 420-428.

HALL, T.A. 1999. BioEdit: a user-friendly biological sequence alignment editor and analysis program for Windows 95/98/NT. - Nucleic Acids Symposium Series 41: 95-98.

HILL, M.O., N. BELL, M.A. BRUGGEMAN-NANNENGA, M. BRUGUÉS, M.J. CANO, J. ENROTH, K.I. FLATBERG, J.-P. FRAHM, M.T. GALLEGO, R. GARILLETI, J. GUERRA, L. HEDENAS, D.T. HOLYOAK, J. HYVÖNEN, M.S. IGNATOV, F. LARA, V. MAZIMPAKA, J. MUÑOZ \& L. SÖDERSTRÖM. 2006. An annotated checklist of the mosses of Europe and Macaronesia. - Journal of Bryology 28: 198-267.

HUTTUNEN, S., L. HEDENÄS, M.S. IGNATOV, N. DEVOS \& A. VANDERPOORTEN. 2008. Origin and evolution of the Northern Hemisphere disjunctions in the moss genus Homalothecium (Brachytheciaceae). - American Journal of Botany 95(6): 720-730

HUTTUNEN, S. \& M.S. IGNATOV. 2004. Phylogetic analysis of Brachytheciaceae (Bryophyta) based on morphology, and sequence level data. - Cladistics 20: 151-183.

HUTTUNEN, S. \& M.S. IGNATOV. 2010. Evolution and taxonomy of aquatic species in the genus Rhynchostegium (Brachytheciaceae, Bryophyta). - Taxon 59: 791-808.

HUELSENBECK, J., \& F RONQUIST. 2001. MRBAYES: Bayesian inference of phylogenetic trees. - Bioinformatics 17: 754-755.

IGNATOV, M.S., O.M. AFONINA, E.A. IGNATOVA et al., 2006. Checklist of mosses of East Europe and North Asia. - Arctoa 15: 1-130.

IGNATOV, M.S. \& S. HUTTUNEN. 2002. Brachytheciaceae (Bryophyta) - a family of sibling genera. - Arctoa 11: 245-296.

IGNATOV, M.S., I.A. MILYUTINA \& V.K. BOBROVA. 2008. Problematic groups of Brachythecium and Eurhynchiastrum (Brachytheciaceae, Bryophyta) and taxonomic solutions suggested by nrITS sequences. Arctoa 17: 113-138.

IGNATOV, M.S. \& I.A. MILYUTINA. 2010. The genus Brachythecium (Brachytheciaceae, Musci) in Russia: comments on species and key for identification. - Arctoa 19: 1-30.

IGNATOV, M.S. 2014: Brachythecium. - In: Flora of North America Editorial Committee, eds., Flora of North America North of Mexico. Vol. 28, pp. 414-428. New York and Oxford.

IWATSUKI, Z. 2004. New catalog of the mosses of Japan. - Journal of the Hattori Botanical Laboratory 96: 1-182.

KUZNETSOVA, O.I., E.A. IGNATOVA, V.E. FEDOSOV, D.YA. TUBANOVA \& M.S. IGNATOV. 2019. Bryophyte molecular barcoding records. - Arctoa 28: 250-251.

NOGUCHI, A. \& Z. IWATSUKI. 1991. Illustrated moss flora of Japan. Pt. 4. - Hattori Botanical Laboratory, Nichinan: 743-1012.

TAKAKI, N. 1955. Researches on the Brachytheciaceae of Japan and its adjacent areas I. - Journal of the Hattori Botanical Laboratory 14: 1-28.

TAKAKI, N. 1955. Researches on the Brachytheciaceae of Japan and its adjacent areas II. - Journal of the Hattori Botanical Laboratory 15: 1-69.

WANG, Y.F. 2008. Brachytheciaceae. - In: Hu, R.-L., Y.-F. Wang, M.R. Crosby \& S. He. 2008. Amblystegiaceae-Plagiotheciaceae. Moss Flora of China. Vol. 7. Science Press \& Missouri Botanical Garden, Beijing, New York \& St. Louis: viii +258 pp. 